\title{
Social Rules and Legal Theory
}

\author{
Ronald M. Dworkin $\dagger$
}

In 1967 I published an article in which I argued that the central propositions of the legal theory I called positivism were in error and must be abandoned. ${ }^{1}$ In particular, I argued that it is wrong to suppose, as that theory does, that in every legal system there will be some commonly recognized fundamental test for determining which standards count as law and which do not. I said that no such fundamental test can be found in complicated legal systems, like those in force in the United States and Great Britain, and that in these countries no ultimate distinction can be made between legal and moral standards, as positivism insists.

I might summarize the argument I made in this way. I said that the thesis that there exists some commonly recognized test for law is plausible if we look only at simple legal rules of the sort that appear in statutes or are set out in bold type in textbooks. But lawyers and judges, in arguing and deciding lawsuits, appeal not only to such blackletter rules, but also to other sorts of standards that I called legal principles, like, for example, the principle that no man may profit from his own wrong. This fact faces the positivist with the following difficult choice. He might try to show that judges, when they appeal to principles of this sort, are not appealing to legal standards, but only exercising their discretion. Or he might try to show that, contrary to my doubts, some commonly-recognized test always does identify the principles judges count as law, and distinguishes them from the principles they do not. I argued that neither strategy could succeed.

A number of lawyers have been kind enough to reply to my argument; the article by Dr. Raz in the present issue of this journal is a distinguished example. ${ }^{2}$ The chief points made against my argument seem to be these. (i) It is not clear, it is said, that my thesis really involves anything more than an amendment to the positivist's doctrine.

$\dagger$ Professor of Jurisprudence and Fellow of University College, Oxford University, and Visiting Lecturer, Yale Law School.

1. Dworkin, The Model of Rules, 35 U. CHr. L. REv. 14 (1967), reprinted under the title Is Law a System of Rules?, in Esstys in LEgal Pulosorur 25 (R. Summers cd. 1969).

2. Raz, Legal Principles and the Limits of Law, 81 YAt.e L.J. 823 (1972). See also G. Carrio, Legal Princirles and Legal Positivisa (1971); Christic, The Alodel of Principles, 1968 Duke L.J. 649; Gross, Jurisprudence, 1968/69 ANNual StRveY of A3. L. J75: Probert. The Right Way, HuMAN RIGHTs 163 (E. Pollack ed. 1971); Sartoritus, Social Policy and Judicial Legislation, 8 Ax. PHI. Q. 151 (1971); Tapper, A Nole on Principles, 1971 MoDern L. Rev. 628. For an earlier article, see MacCallum, Duorlin on Iudicial Discretion, 60 J. PHIL. 638 (1963). I do not attempt to reply to or even mention all the points and questions presented in these articles. I have selected for discussion those points made most often, or found most persuasive by students. 
If one reads carefully the work of Professor H. L. A. Hart, whose work I took to be the clearest example of a positivist theory, one will see that his theory is able to include my conclusions with only minor amendment. ${ }^{3}$ (ii) It is said that my own arguments are inconsistent in this way: my argument against the theory of discretion supposes that in fact some principles do and some principles do not count as law, but if this is so then there must be a test for law of just the sort that I deny. ${ }^{4}$ (iii) The arguments I make, moreover, suggest the form of this ultimate test. I said that judges identify principles at least in part by reference to the role that these principles have played in previous legal argument, and this kind of test, which I described as a test of "institutional structure,"s can supply the ultimate test for principles that I say cannot be found. (iv) My argument that judges do not have discretion in the matter of principles ignores the fact that judges may sometimes be forced to exercise discretion by virtue of the fact that it is not plain which principles count and for how much. ${ }^{6}$ (v) The distinction between rules and principles, on which my argument seems to depend, is in fact untenable. ${ }^{\text {? }}$

There is a further objection, which might be made, but which I shall not try to answer. I have no answer to the argument that the term "law" can be used in such a way as to make the positivist's thesis true by stipulation. It can be used, that is, in such a way that the speaker recognizes as "legal" standards only those standards judges and lawyers cite which are in fact identified by some commonly-recog. nized test. No doubt "law" can be used in that way, and perhaps some lawyers do so. But I was concerned with what I took to be an argument about the concept of law now in general employment, which is, I take it, the concept of the standards that provide for the rights and duties that a government has a duty to recognize and enforce, at least in principle, through the familiar institutions of courts and police. My point was that positivism, with its doctrine of a fundamental and commonly-recognized test for law, mistakes part of the domain of that concept for the whole.

Before I turn to the specific objections I listed, however, I want to consider one very general objection that I did not list, but which I believe, for reasons that will be clear, underlines several of those I did. This general objection depends on a thesis that Hart defended in The

3. See, e.g., Carrio, supra note 2, at 22.

4. Sartorius, supra note 2, at 155 .

5. Id. at 156.

6. Raz at 843 ff., CARRIo, supra note 2, at 27; Christie, supra note 2, at 669; MacCallum, supra note 2.

7. Raz at $834-54$, Christie, supra note 2 , at 656 ff. 
Concept of Law, ${ }^{8}$ a thesis which belongs to moral as well as to legal philosophy. It argues, in its strongest form, that no rights or duties of any sort can exist except by virtue of a uniform social practice of recognizing these rights and duties. If that is so, and if law is, as I suppose, a matter of rights and duties and not simply of the discretion of officials, then there must be a commonly recognized test for law in the form of a uniform social practice, and my argument must be wrong.

In the first section of this essay I shall elaborate this powerful thesis, with special reference to the duty of judges to apply particular standards as law. I shall then argue that the thesis must be rejected. In the remaining sections I shall, on some occasions, recast my original arguments to show why they depend on rejecting it.

\section{Social Rules}

I shall begin by noticing an important distinction between two of the several types of concepts we use when we discuss our own or other people's behavior. Sometimes we say that on the whole, all things considered, one "ought" or "ought not" to do something. On other occasions we say that someone has an "obligation" or a "duty" to do something, or "no right" to do it. These are different sorts of judgments: it is one thing, for example, simply to say that someone ought to give to a particular charity and quite another to say that he has a duty to do so, and one thing to say simply that he ought not to drink alcohol or smoke marijuana and quite another to say that he has no right to do so. It is easy to think of cases in which we should be prepared to make the first of each of these claims, but not the second.

Moreover, something might well turn, in particular cases, on which claim we did feel was justified. Judgments of duty are commonly much stronger than judgments simply about what one ought to do. We can demand compliance with an obligation or a duty, and sometimes propose a sanction for non-compliance; but neither demands nor sanctions are appropriate when it is merely a question of what one ought, on the whole, to do. The question of when claims of obligation or duty are appropriate, as distinct from such general claims about conduct, is therefore an important question of moral philosophy, though it is a relatively neglected one.

The law does not simply state what private citizens ought or ought not to do; it provides what they have a duty to do or no right to do. It does not, moreover, simply advise judges and other officials about

8. H.L.A. Hart, The Concept of Law 79-88 (1961). 
the decisions they ought to reach; it provides that they have a duty to recognize and enforce certain standards. It may be that in some cases a judge has no duty to decide either way; in this sort of case we must be content to speak of what he ought to do. This, I take it, is what is meant when we say that in such a case the judge has "discretion." But every legal philosopher, with the exception of the most extreme of the American legal realists, has supposed that in at least some cases the judge has a duty to decide in a particular way, for the express reason that the law requires that decision.

But it is a formidable problem for legal theory to explain why judges have such a duty. Suppose, for example, that a statute provides that in the event of intestacy a man's property descends to his next of kin. Lawyers will say that a judge has a duty to order property distributed in accordance with that statute. But what imposes that duty on the judge? We may want to say that judges are "bound" by a general rule to the effect that they must do what the legislature says, but it is unclear where that rule comes from. We cannot say that the legislature is itself the source of the rule that judges must do what the legislature says, because that explanation presupposes the rule we are trying to justify. Perhaps we can discover a basic legal document, like a constitution, that says either explicitly or implicitly that the judges must follow the legislature. But what imposes a duty on judges to follow the constitution? We cannot say the constitution imposes that duty without begging the question in the same way.

If we were content to say merely that judges ought to follow the legislature, or the constitution, then the difficulty would not be so serious. We might provide any number of reasons for this limited claim; for example, that everyone would be better off in the long run, on balance, if judges behaved in this way. But this sort of reason is unpersunsive if we want to claim, as our concept of law seems to assume, that judges have a duty to follow the legislature or the constitution. We must then try to find, not just reasons why judges should do so, but grounds for asserting that duty, and this requires that we face the issue of moral philosophy I just named. Under what circumstances do duties and obligations arise?

Hart's answer may be summarized in this way. ${ }^{\circ}$ Duties exist when social rules exist providing for such duties. Such social rules exist when the practice-conditions for such rules are met. These practice-condi-

9. Hart's analysis, supra note 8, is of the concept of "obligation." I use the word "duty" here as well because it is more usual to speak of the judge's duty than of his obligation to impose the law, and because Hart means his analysis to apply to both terms; indecd he uses them almost interchangeably in THE CONCEIrr of LAw. See id. at 27, 238. 
tions are met when the members of a community behave in a certain way; this behavior constitutes a social rule, and imposes a duty. Suppose that a group of churchgoers follows this practice: (a) each man removes his hat before entering church, (b) when a man is asked why he does so, he refers to "the rule" that requires him to do so, and (c) when someone forgets to remove his hat before entering church, he is criticized and perhaps even punished by the others. ${ }^{10}$ In those circumstances, according to Hart, practice-conditions for a duty-imposing rule are met. The community "has" a social rule to the effect that men must not wear hats in church, and that social rule imposes a duty not to wear hats in church. That rule takes the issue of hat-wearing in church out of the general run of issues which men may debate in terms of what they ought to do, by creating a duty. The existence of the social rule, and therefore the existence of the duty, is simply a matter of fact.

Hart then applies this analysis to the issue of judicial duty. He believes that in each legal system the practice-conditions are met, by the behavior of judges, for a social rule that imposes a duty to identify and apply certain standards as law. If, in a particular community, these officials (a) regularly apply the rules laid down by the legislature in reaching their decisions, (b) justify this practice by appeal to "the rule" that judges must follow the legislature, and (c) censure any official who does not follow that rule, then, on Hart's theory, this community can be said to have a social rule that judges must follow the legislature. If so, then judges in that community have a duty to do so. If we now ask why judges have a duty to follow social rules, after the fashion of our earlier quibbles, Hart will say that we have missed the point. It belongs to the concept of a duty, on his account, that duties are created by social rules of the sort he describes.

But Hart's theory, as so far presented, is open to an objection that might be put in the following way. When a sociologist says that a particular community "has" or "follows" a particular rule, like the nohat-in-church rule, he means only to describe the behavior of that community in a certain respect. He means only to say that members of that community suppose that they have a particular duty, and not that he agrees. But when a member of the community himself appeals to a rule, for the purpose of criticizing his own or someone else's behavior, then he means not simply to describe the behavior of other people but to evaluate it. He means not simply that others believe that they have a certain duty, but that they do have that duty. We

10. Hart uses this example for a different purpose. See HART, supra note 8, at 121. I have drafted the example so that the social rule here in play would be an obligation (or duty) imposing rule, e.g., by providing that the social pressures for confornity are severe. 
must therefore recognize a distinction between two sorts of statements each of which uses the concept of a rule. The sociologist, we might say, is asserting a social rule, but the churchgoer is asserting a normative rule. We might say that the sociologist's assertion of a social rule is true (or warranted) if a certain factual state of affairs occurs, that is, if the community behaves in the way Hart describes in his example. But we should want to say that the churchgoer's assertion of a normative rule is true (or warranted) only if a certain normative state of affairs exists, that is, only if individuals in fact do have the duty that they suppose they have in Hart's example. The judge trying a lawsuit is in the position of the churchgoer, not the sociologist. He does not mean to state, as a cold fact, simply that most judges believe that they have a duty to follow what the legislature has said; he means that they do in fact have such a duty and he cites that duty, not others' beliefs, as the justification for his own decision. If so, then the social rule cannot, without more, be the source of the duty he believes he has.

Hart anticipates this objection with an argument that forms the heart of his theory. He recognizes the distinction I have drawn between assertions of a "social rule" and assertions of a "normative rule," though he does not use these terms. However, he denies, at least as to the cases he discusses, that these two sorts of assertions can be said to assert two different sorts of rules. Instead, he asks us to distinguish between the existence of a rule and its acceptance by individual members of the community in question. When the sociologist asserts the existence of a social rule he merely asserts its existence; he says only that the practice-conditions for that rule have been met. When the churchgoer asserts its existence he also claims that these practice-conditions are met, but in addition he displays his acceptance of the rule as a standard for guiding his own conduct and for judging the conduct of others. He both identifies a social practice and indicates his disposition to conform his behavior to it. The sociologist (in Hart's language) takes an "external" view of the practice, while the churchgoer takes an "internal" view of it. Nevertheless, insofar as each refers to a rule, it is the same rule, that is, the rule that is constituted by the social practice in question.

The difference between a statement of a social rule and a statement of a normative rule, then, is not a difference in the type of rule each asserts, but rather a difference in the attitude each displays towards the social rule it does assert. When a judge appeals to the rule that whatever the legislature enacts is law, he is taking an internal point of view towards a social rule; what he says is true because a social practice to 
that effect exists, but he goes beyond simply saying that this is so. He signals his disposition to regard the social practice as a justification for his conforming to it.

So Hart advances both a general theory about the concept of obligation and duty, and a specific application of that theory to the duty of judges to enforce the law. For the balance of this initial section, I shall be concerned to criticize the general theory, which I shall call the social rule theory, and I shall distinguish strong and weaker versions of that theory. On the strong version, whenever anyone asserts a duty he must be understood as presupposing the existence of a social rule and signifying his acceptance of the practice the rule describes. So if I say that men have a duty not to lie, I must mean at least that a social rule exists to that effect, and unless it does my statement must be false. On a weaker version, it is simply sometimes the case that someone who asserts a duty must be understood as presupposing a social rule that provides for that duty. For example, it might be the case that a churchgoer who says that men must not wear hats in church must be understood in that way, but it would not follow that the man who asserts a duty not to lie must be understood in the same way. He might be asserting a duty that does not in fact depend upon the existence of a social rule.

Hart does not make entirely plain, in the relevant pages of The Concept of Law, which version he means to adopt, though much of what he says suggests the strong version. But the application of his general theory to the problem of judicial duty will, of course, depend upon which version of the social rule theory he means to make out. If the strong version is right, then judges who speak about a fundamental duty to treat what the legislature says as law, for example, must presuppose a social rule to that effect. But if some weaker version of the social rule theory holds, then it simply might be the case that this is so, and further argument would be needed to show that it is.

The strong version of the theory cannot be correct if it proposes to explain all cases in which people appeal to duties, or even to all cases in which they appeal to rules as the source of duties. The theory must concede that there are some assertions of a normative rule that cannot be explained as an appeal to a social rule, for the reason that no corresponding social rule exists. A vegetarian might say, for example, that we have no right to kill animals for food because of the fundamental moral rule that it is always wrong to take life in any form or under any circumstance. Obviously no social rule exists to that effect; the vegetarian will acknowledge that very few men now recognize any such rule or any such duty and indeed that is his complaint. 
However, the theory might argue that this use of the concepts of rule and duty designates a special case, and belongs in fact to a distinct kind of moral practice that is parasitic upon the standard practice the theory is designed to explain. The vegetarian must be understood, on this account, really to be saying not that men and women presently have a duty not to take life, but rather that since there are very strong grounds for saying that one ought not to take life, a social rule to that effect ought to exist. His appeal to "the rule" might suggest that some such rule already does exist, but this suggestion is a sort of figure of speech, an attempt on his part to capture the imperative force of social rules, and extend that force to his own very different sort of claim.

But this defense misunderstands the vegetarian's claim. He wants to say, not simply that it is desirable that society rearrange its institutions so that no man ever has the right to take life, but that in fact, as things stand, no one ever does have that right. Indeed, he will want to urge the existence of a moral duty to respect life as a reason why society should have a social rule to that effect. The strong version of the social rule theory does not permit him to make that argument. So that theory can accommodate his statements only by insisting that he say something that he does not want to say.

If the social rule theory is to be plausible, therefore, it must be weakened at least to this extent. It must purport to offer an explanation of what is meant by a claim of duty (or an assertion of a normative rule of duty) only in one sort of case, namely, when the community is by-and-large agreed that some such duty does exist. The theory would not apply in the case of the vegetarian, but it would apply in the case of the churchgoer. This weakening would not much affect the application of the theory to the problem of judicial duty, because judges do in fact seem to follow much the same rules in deciding what to recognize as the law they are bound to enforce.

But the theory is not plausible even in this weakened form. It fails to notice the important distinction between two kinds of social morality, which might be called concurrent and conventional morality. A community displays a concurrent morality when its members are agreed in asserting the same, or much the same, normative rule, but they do not count the fact of that agreement as an essential part of their grounds for asserting that rule. It displays a conventional morality when they do. If the churchgoers believe that each man has a duty to take off his hat in church, but would not have such a duty but for some social practice to that general effect, then this is a case of conventional morality. If they also believe that each man has a duty not 
to lie, and would have this duty even if most other men did, then this would be a case of concurrent morality.

The social rule theory must be weakened so as to apply only to cases of conventional morality. In cases of concurrent morality, like the lying case, the practice-conditions Hart describes would be met. People would on the whole not lie, they would cite "the rule" that lying is wrong as a justification of this behnvior, and they would condemn those who did lie. A social rule would be constituted by this behavior, on Hart's theory, and a sociologist would be justified in saying that the community "had a rule" against lying. But it would distort the claim that members of the community made, when they spoke of a duty not to lie, to suppose them to be appealing to that social rule, or to suppose that they count its existence necessary to their claim. On the contrary, since this is a case of concurrent morality, the fact is that they do not. So the social rule theory must be confined to conventional morality.

This further weakening of the theory might well reduce its impact on the problem of judicial duty. It may be that at least some part of what judges believe they must do represents concurrent rather than conventional morality. Many judges, for example, may believe that they have a duty to enforce decision of a democratically elected legislature on the grounds of political principles which they accept as having independent merit, and not simply because other judges and officials accept them as well. On the other hand, it is at least plausible to suppose that this is not so, and that at least the bulk of judges in typical legal systems would count some general judicial practice as an essential part of the case for any claim about their judicial duties.

However, the social rule theory is not even an adequate account of conventional morality. It is not adequate because it cannot explain the fact that even when people count a social practice as a necessary part of the grounds for asserting some duty, they may still disagree about the scope of that duty. Suppose, for example, that the members of the community which "has the rule" that men must not wear hats in church are in fact divided on the question of whether "that" rule applies to the case of male babies wearing bonnets. Each side believes that its view of the duties of the babies or their parents is the sounder, but neither view can be pictured as based on a social rule, because there is no social rule on the issue at all.

Hart's description of the practice-conditions for social rules is explicit on this point: a rule is constituted by the conforming behavior of the bulk of a population. No doubt he would count, as conforming 
behavior, behavior that everyone agrees would be required in a particular case even though the case has not arisen. So the social rule would "cover" the case of a red-headed man, even if the community did not happen to include one as yet. But if half the churchgoers claim that babies are required to take off their bonnets and the other half denies any such requirement, what social rule does this behavior constitute? We cannot say either that it constitutes a social rule that babies must take off their bonnets, or a social rule that provides that they do not have that duty.

We might be tempted to say that the social rule about men wearing hats in church is "uncertain" as to the issue of babies. But this involves confusion of just the sort that the social rule theory is meant to avoid. We cannot say that the social rule is uncertain when all the relevant facts about social behavior are known, as they are in this case, because that would violate the thesis that social rules are constituted by behavior. A social rule about wearing hats in church might be said to be uncertain when the facts about what people did and thought had not yet been gathered, or, perhaps, if the question of babies had not yet arisen, so that it was unclear whether the bulk of the community would be of one mind or not. But nothing like this kind of uncertainty is present here; the case has arisen and we know that members of the community do not agree. So we must say, in this kind of case, not that the social rule about wearing hats in church is uncertain, but rather that the only social rule that the behavior of the community constitutes is the rule that prohibits grown men from wearing hats in church. The existence of that rule is certain, and it is equally certain that no social rule exists on the issue of babies at all.

But all this seems nearly fatal to the social rule theory, for this reason: when people assert normative rules, even in cases of conventional morality, they typically assert rules that differ in scope or in detail, or, in any event, that would differ if each person articulated his rule in further detail. But two people whose rules differ, or would differ if elaborated, cannot be appealing to the same social rule, and at least one of them cannot be appealing to any social rule at all. This is so even though they agree in most cases that do or might arise when the rules they each endorse are in play. So the social rule theory must be weakened to an unacceptable form if it is to survive at all. It must be held to apply only in cases, like some games, when it is accepted by the participants that if a duty is controversial it is no duty at all. It would not then apply to judicial duties.

The theory may try to avoid that conclusion in a variety of ways. 
It might argue, first, that when someone appeals to a rule, in a controversial case, what he says must be understood as having two parts: first, it identifies the social rule that does represent agreement within the community (that grown men must not wear hats in church) and then it urges that this rule ought to be extended to cover more controversial cases (babies in church). The theory might, in other words, take the same line towards all controversial appeals to rules as I said it might in the case of the vegetarian. But the objection I made in discussing the vegetarian's case could then be made, with much greater effect, as a general critique of the theory as a whole. People, at least people who live outside philosophy texts, appeal to moral standards largely in controversial circumstances. When they do, they want to say not that the standard ought to apply to the case at hand, whatever that would mean, but that the standard does apply; not that people ought to have the duties and responsibilities that the standard prescribed, but that they do have them. The theory could hardly argue that all these claims are special or parasitic employments of the concept of duty; if it did, it would limit its own application to the trivial.

The theory might be defended, alternatively, in a very different way: by changing the concept of a social rule that it employs. It might do this by fixing on the fact that, at least in the case of conventional morality, certain verbal formulations of a rule often become standard, like the form, "men must take off their hats in church." On the revised concept, a social rule exists when a community accepts a particular verbal formulation of its duties, and uses that formulation as a guide to conduct and criticism; the rule can then be said to be "uncertain" to the degree that the community disagrees about the proper application of some one or more terms in the standard formulation, provided that it is agreed that the controversial cases must be decided on the basis of one or another interpretation of these terms. The revision would provide an answer to the argument I made. The churchgoers do accept one single social rule about their hat-wearing responsibilities, namely the rule that men must not wear hats in church. But that rule is uncertain, because there is disagreement whether "men" includes male babies, or whether "hats" includes bonnets.

But this revision of the concept places much too much weight upon the accident of whether members of the community in question are able to, or do in fact, locate their disagreements about duties as disagreements in the interpretation of some key word in a particular verbal formulation that has become popular. The churchgoers are able to put their disagreement in this form, but it does not follow that they 
all will. The verbal formulation of the rule might have been different without the underlying social facts having been different, as if people were in the habit of saying that only women may cover their heads in church; in that case the disagreement would have to be framed, not as a disagreement over whether "women" includes "male babies" but whether the popular version was a correct statement of the right normative rule.

Moreover, the theory would lose most of its original explanatory power if it were revised in this way. As originally presented it captured, though it misrepresented, an important fact, which is that social practice plays a central role in justifying at least some of our normative claims about individual responsibility or duty. But it is facts of consistent practice that count, not accidents of verbal behavior. Our moral practices are not exercises in statutory interpretation.

Finally, the social rule theory might retain Hart's original definition of a social rule, as a description of uniform practice, but retreat in a different way and cut its losses. It might give up the claim that social rules ever set the limit of a man's duties, but keep the idea that they set their threshold. The function of social rules in morality might then be said to be this: social rules distinguish what is settled by way of duties, not simply in the factual sense that they describe an area of consensus, but in the conceptual sense that when such consensus exists, it is undeniable that members of that community have at least the duties it embraces, though they may, and perhaps may properly, refuse to honor these duties. But the social rule does not settle that individuals have no rights or duties beyond its terms even in the area of conventional morality; the fact that the social rule does not extend to some case, like the case of babies in church, means rather that someone asserting a duty in that case must rely on arguments that go beyond a simple appeal to practice.

If the social rule theory is revised in this way it no longer supports Hart's thesis of a social rule of recognition in the way that the original theory I described does. If judges may have a duty to decide a case in a particular way, in spite of the fact that no social rule imposes that duty, then Hart's claim that social practice accounts for all judicial duty is lost. I should like to point out, however, the weakness that remains in even this revised form of the social rule theory. It does not conform with our moral practice to say even that a social rule stipulates the minimum level of rights and duties. It is generally recognized, even as a feature of conventional morality, that practices that are pointless, or inconsistent in principle with other requirements of morality, do 
not impose duties, though of course, when a social rule exists, only a small minority will think that this provision in fact applies. When a social rule existed, for example, that men extend certain formal courtesies to women, most people said that women had a right to them; but someone of either sex who thought these courtesies an insult would not agree.

This fact about conventional morality, which the social rule theory ignores, is of great importance because it points toward a better understanding of the connection between social practice and normative judgments than that theory provides. It is true that normative judgments often assume a social practice as an essential part of the case for that judgment; this is the hallmark, as I said, of conventional morality. But the social rule theory misconceives the connection. It believes that the social practice constitutes a rule which the normative judgment accepts; in fact the social practice helps to justify a rule which the normative judgment states. The fact that a practice of removing hats in church exists justifies asserting a normative rule to that effect-not because the practice constitutes a rule which the normative judgment describes and endorses, but because the practice creates ways of giving offense and gives rise to expectations of the sort that are good grounds for asserting a duty to take off one's hat in church or for asserting a normative rule that one must.

The social rule theory fails because it insists that a practice must somehow have the same content as the rule that individuals assert in its name. But if we suppose simply that a practice may justify a rule, then while the rule so justified may have the same content as the practice, it may not; it may fall short of, or go beyond it. If we look at the relationship between social practice and normative claims in this way, then we can account, smoothly, for what the social rule theory labors to explain. If someone finds a social practice pointless, or silly, or insulting, he may believe that it does not even in principle justify asserting any duties or normative rules of conduct, and in that case he will say, not that it imposes a duty upon him which he rejects, but that, in spite of what others think, it imposes no duty at all.

If a community has a particular practice, moreover, like the no-hatin-church practice, then it will be likely, rather than surprising, that members will assert different normative rules, each allegedly justified by that practice. They will disagree about whether babies must wear bonnets because they will differ about whether, all things considered, the fact of the practice justifies asserting that duty. Some may think that it does because they think that the practice as a whole establishes 
a form of insult or disrespect that can be committed vicariously by an infant's parents. Others may disagree, for a variety of reasons. It is true that they will frame their dispute, even in this trivial case, as a dispute over what "the rule" about hats in church requires. But the reference is not to the rule that is constituted by common behavior, that is, a social rule, but the rule that is justified by common behavior, that is, a normative rule. They dispute precisely about what that rule is.

It may be that judicial duty is a case of conventional morality. It does not follow that some social rule states the limit, or even the threshold, of judicial duty. When judges cite the rule that they must follow the legislature, for example, they may be appealing to a normative rule that some social practice justifies, and they may disagree about the precise content of that normative rule in a way that does not represent merely a disagreement about the facts of other judges' behavior. The positivist may be right, but he must make out his case without the short-cut that the social rule theory tries to provide.

\section{Do I Really Disagree with Hart?}

It has been suggested that my disagreement with positivism, at least in the form presented by Hart, is not really so broad as I have claimed. Perhaps I have shown that a sensible account of law would have a place for principles as well as rules. But nothing in Hart's theory seems to deny this. It is true that he speaks only about rules, but he does not define "rule" in the limited way in which I define that term in my article, and he might therefore be understood, when he spenks of rules, to include principles as well as rules in a narrow sense. Perhaps I have shown that any fundamental test for law, if it is to include principles as well as rules of law, must be more complex than the examples Hart offers as specimens of a rule of recognition. But Hart says that the rule of recognition may be complex; that it may be composed, indeed, of several criteria arranged in a hierarchy. His simple examples-like the rule that what the Queen in Parliament enacts is law-are intended to be merely examples.

Where then does the disagreement lie? It is true that in my article I appear to deny Hart's thesis, that every legal system has a fundamental test for law in the form of a rule of recognition. But, as Pro. fessor Sartorius points out, I cannot really mean that a legal system can exist which has no fundamental test for identifying rules and principles of law.11 It was part of my argument that some principles

11. Sartorius, supra note 2 , at 155. 
must be considered as law, and therefore figure in judicial argument, while others may not. But if that is true, then there must be some sort of test that can be used to distinguish the two. So my statement that no such fundamental rule exists must be understood as meaning merely that the fundamental test must be too complex to state in a simple rule. But since Hart never argued that the fundamental rule must be a simple one, this point of difference is limited.

So runs the first of the objections I want to consider. When I wrote my original article I thought that the positivist's thesis, that a fundamental test for law exists in every legal system, was sufficiently clear as to need very little elaboration. I thought that any ambiguities could be resolved by taking Professor Hart's careful formulation of that thesis as an example. The objection I have just described convinces me that I was wrong in this, and I shall now try to repair the damage by stating more clearly what I take the positivists' claim to be, and how that claim differs from claims that I myself would want to make.

I shall start by setting out three different theses, each of which has something to do with the idea of a fundamental test for law. In describing these different theses, I shall make use of the distinction I made in the last section, the distinction between describing social behavior through the concept of a social rule, on the one hand, and asserting a normative position through the concept of a normative rule, on the other. (i) The first thesis holds that, in every nation which has a developed legal system, some social rule or set of social rules exists within the community of its judges and legal officials, which rules settle the limits of the judge's duty to recognize any other rule or principle as law. The thesis would hold for England, for example, if English judges as a group recognized a duty to take into account, when determining legal rights and obligations, only rules or principles enacted by Parliament, or laid down in judicial decisions, or established by long standing custom, and recognized, as a group, that they had no duty to take into account anything else. Hart advances this first thesis; in fact, his theory that a social rule of recognition exists in every legal system may be regarded as one of the most important contributions he has made to the positivist tradition. (ii) The second thesis holds that in every legal system some particular normative rule or principle, or complex set of these, is the proper standard for judges to use in identifying more particular rules or principles of law. Someone who accepts this second thesis might believe, for example, that in England judges have a duty to recognize only statutes, 
precedents and clear customs as law, whether or not they actually reach their decisions in that fashion. (iii) The third thesis holds that in each legal system most of the judges accept some normative rule or theory governing their duty to count other standards as legal standards. This thesis argues that if one studies the patterns of decisions of the various English judges, for example, one would find that each judge, more or less consciously, follows a particular rule designating certain exclusive sources of law, or a more complex theory stipulating how law is to be found. It would not follow from this thesis, though it might also be true, that the bulk of the English judges follow the same rule or theory; if they did, then the first thesis would also be true of England, at least, but not otherwise.

The disagreement between Hart and myself is about the first of these three theses. He proposes that thesis, and I deny it. The issue is important; upon it hinges the orthodox idea that legal standards can be distinguished in principle and as a group from moral or political standards. If the first thesis is right, then in every legal system some commonly-accepted test does exist for law, in the shape of a social rule, and this is enough to distinguish legal from moral rules and principles. But if the first thesis is false, then no such test exists.

It is not enough that some version of the second or third thesis might be sound. Suppose that I myself accept a normative theory of law of the sort contemplated by the second thesis. My theory, if it is not shared by everyone else, will include controversial provisions; it might include, for example, a controversial theory of precedent that argues that courts must give more weight to recent than to out-of-date precedents. I would then be required to support the claim that my view of precedent correctly states a judge's duty, and I could do so only by deploying a further theory about the point or value of the institution of precedent. My case for this further theory would no doubt depend on controversial principles of political morality, principles, for example, about the proper place of a judiciary in a democracy. It is just this sort of dependence that positivism is most concerned to deny.

The distinctions I have drawn between these three different theses show why Sartorius's objection misses the point. He thinks that if I say that judges have a duty to use some principles but not others, or to assign a given weight to one principle but not a greater weight, it follows that I myself am committed to the idea that there is a fundamental test for law. It does follow that I am committed to some version of the second thesis, that is, that I myself think that a persuasive case 
can be made in support of one theory rather than some other about how judges must decide hard cases. But it does not follow that I must accept the first thesis, that some social rule exists among judges that settles that issue. That is Hart's thesis, but it is not, nor need it be, mine.

However, one feature of Hart's theory suggests that I attribute to him too rigid a theory. $\mathrm{He}$ is careful to say that a social rule of recognition might be uncertain in some cases, so that it does not settle every issue that might arise about what counts as law.12 It is enough, for such a rule to exist, that it settles most such issues. He gives this example. There is no doubt, he says, that it is at least part of the rule of recognition of England that whatever Parliament enacts is law. It is nevertheless uncertain whether Parliament now has the power to bind future Parliaments, as it might try to do if, for example, it adopted a particular rule of law, and then entrenched both that rule and the entrenching provision by providing that neither could be repealed except by a two-thirds majority. If this happened, judges might well be divided as to the legal consequences of an attempt by a future Parliament to repeal these rules by a simple majority. If judges were so divided, this would show that the rule of recognition is uncertain on this point, and the issue could only then be settled, and the rule of recognition clarified, if some court made the decision one way or the other, and turned out to have the power to make its decision stick.

So Hart, it might seem, is not committed to the notion that in every legal system some social rule exists that settles all issues of which standards count as law. It is enough to establish the first thesis, he might say, that a social rule is treated as governing all decisions of law, even though it is not so precise that what it requires is never open to dispute. He might then add that when judges are in fact divided (as they would be about entrenchment, or, to continue my own example, about the force to be given to older precedents) they reveal an area of uncertainty within a social rule that is for the most part certain.

But Hart's qualification, that the rule of recognition may be uncertain at particular points, does not simply add flexibility and sophistication to his theory. On the contrary, it undermines it, for reasons I tried to make plain in the last section. It simply does not fit the concept of a social rule, as Hart uses that concept, to say that a social rule may be uncertain in the sense that Hart now has in mind. If judges are in fact divided about what they must do if a subsequent

12. HART, supra note 8 , at 144. 
Parliament tries to repeal an entrenched rule, then it is not uncertain whether any social rule governs that decision; on the contrary, it is certain that none does. The example simply shows that the statement, that in England a social rule exists among judges to the effect that whatever Parliament enacts is law, is strictly speaking inaccurate, though it might be accurate enough for most purposes.

A careful statement of the position, using the concept of a social rule, would have to be made along these lines. A social rule exists among judges to the effect that whatever Parliament enacts, short of a law purporting to bind future Parliaments, is law. No social rule exists on the issue of whether Parliament can bind future Parlinments; on this issue judges are divided. Some think that it can, and that they therefore have a duty not to recognize any purported repeal of an entrenched rule as law. Others think that it cannot and that they therefore have a duty to recognize repealing legislation as law. (This simple formulation ignores the more complex positions that different judges might in fact take.)

But, of course, putting the matter that way offers a counter-example to the claim of the first thesis, that some social rule always exists that stipulates necessary and sufficient conditions for what judges must recognize as law. If such disagreements among judges were limited only to extraordinary and rare cases, like entrenchment clauses, then such counter-examples would be few, and offer no real impediment to the claim. But if, as I suppose, disagreements among judges of this sort are very frequent, and indeed can be found whenever appellant tribunals attempt to decide difficult or controversial cases, then the general weakness this argument discloses is fatal.

It might now be said that I take too literally Hart's statement that the rule of recognition is a social rule constituted by the common behavior of the members of a particular community, like judges and other officials. He might want to revise that strict concept in the manner I suggested in the last section, to say that a rule of recognition exists as a social rule when judges accept a particular verbal formulation of their duty, like the verbal formulation, "Whatever Parliament enacts is law." If so, then Hart may say that a social rule of recognition exists, but is nevertheless uncertain, when members of the community disagree about the proper application of that verbal formulation to particular cases. So the rule of recognition, that whatever Parliament does is law, exists as a social fact, but it is uncertain to the degree that judges disagree over particular cases like the case of entrenched statutes.

But this revision of the concept, as I said earlier, places too much 
weight upon accidents of language and history. The present example confirms this. It may be conventional to say that whatever Parliament enacts is law. But it is hardly possible to frame the disagreement about entrenched statutes as a disagreement about the proper interpretation of terms within that conventional formulation. No one would say that the controversy was over the meaning of "whatever" or what force should be given to the term "enacts." Nor can many of the more pedestrian and numerous controversies I had in mind, like disagreement about the weight to be given to older precedents, be described as disagreements about the meaning of terms within some settled verbal formula.

Someone might take a different objection to my argument. He would remind me of the distinction I made in the last section, between statements about what judges ought to do and statements about what they have a duty to do. The first thesis does not claim that a social rule always exists that decides what judges ought to do in controversial cases like the entrenchment case. It claims only that a social rule stipulates what judges are required to do in such cases; the limit, that is, of their duties. If judges do disagree about whether to enforce a statute purporting to repeal an entrenched rule, the very fact of this disagreement, according to this objection, would show that judges have no duty either way. The matter would then be one that is left to their discretion, until some court, by the force of its decision one way or the other, encourages other judges to accept that decision as creating a duty.

If this were so, then the first thesis would be immune from the argument I made. But why should we suppose that it is so? The objection depends upon an assumption of moral philosophy. It assumes that duties cannot be controversial in principle. It assumes that if it is not plain what a judge's duty is, and not agreed what further evidence would decide the question, then he cannot have any duty, and we must only speak about what he ought to do. But that assumption is at least questionable. It does not square with the way we use the concept of duty in moral argument. The vegetarian need not accept that our duties are limited to what are uncontroversially or demonstrably our duties. It does not even square with how lawyers treat the issue of judicial duty. In the entrenchment clause dispute, for example, the one proposition that is common ground amongst the disputants is that the matter is not one in which judges are free to exercise discretion. Those who think that Parliament does have power to bind its successors believe that judges have no right to recognize a subsequent attempt at repeal. Those who believe that Parliament does not have this power 
believe that judges have a duty to recognize the subsequent repealer. It is true that some judges might be uncertain. But they are uncertain about their duties, not certain that they have none. Of course, if the strong version of the social rule theory were right, the assumption I described would be sound. But since that theory is false, some other support for the assumption must be found, and none, I think, can.

I hope that no one will want to say that in this sort of case judges are disagreeing about their political or moral duty as judges, but not about their legal duty. The only ground for this distinction is one which, in this context, plainly begs the question. The first thesis I distinguished is designed to explain the distinction the positivist draws between legal and other sorts of duties, and so it cannot assume that distinction. Hart himself says that the fundamental rule of recognition is a legal rule only in the sense in which the standard metre bar in Paris is one metre long; ${ }^{13}$ if judges have a duty to enforce entrenchment clauses, that must be a legal duty in just that sense. But the question of terminology is beside the point. If judges may have a duty to apply some rule or principle in their determination of what the law requires, in spite of the fact that no social rule provides for that duty, then the first thesis is wrong, however that duty is described.

\section{Does "Institutional Support" Constitute a Rule of Recognition?}

In my original article I said that principles, like the principle that no man may profit from his own wrong, could not be captured by any simple rule of recognition, like the rule that what Parliament enacts is law. The positivist, I said, has this choice. He might argue that these principles are not part of the law, because the judge has no duty, but only a discretion, to take them into account. Or he might concede that they are law, and show how a more complicated social rule of recognition might be constructed that does capture such principles. Of course, the positivist might combine these strategies: he might argue that a more complex rule of recognition would capture some of the principles that judges cite, and then argue that judges have no duty to enforce any principles but these.

Dr. Raz wishes to combine both strategies in that way. His principal reliance is on the argument, which I shall consider in the next section, that judges have a discretion, but no duty to employ certain principles. But he believes that judges do have a duty to take into account at least some principles, and that these can be brought under something

13. HART, supra note 8 , at 106. 
like a social rule of recognition, through the notion of what he calls a "judicial custom."14 Suppose a particular principle is in fact cited by many judges over a period of time as a principle that must be taken into account. Then that very practice, he points out, would constitute a distinct social rule which would then stand, along with rules of recognition of the conventional sort that Hart had in mind, within a cluster of social rules that together provide a test for law.

But, for two reasons, this concept of judicial custom cannot carry the argument very far. First, the great bulk of the principles and policies judges cite are controversial, at least as to weight; the weight of the principle that no man may profit from his own wrong, for example, was sufficiently controversial to provoke a dissent in Riggs $v$. Palmer. ${ }^{15}$ Second, a great many appeals to principle are appeals to principles that have not been the subject of any judicial practice at all; this is true of several of the examples I gave from the decision in the Henningsen case, which included principles that had not in fact been formulated before, in anything like the same fashion, like the principle that automobile manufacturers have a special responsibility to the public.

So Raz's notion of judicial custom would not distinguish many of the principles that judges treat as principles they must take into account. We shall therefore have to consider very seriously his argument that judges in fact have no duty to give effect to principles that are not the subject of such a judicial custom. But first I want to consider a different and more complex idea of how the notion of a social rule of recognition can be adapted to capture principles as well as rules.

Professor Sartorius agrees with me in rejecting the idea that when judges appeal to principles in hard cases they do so in the exercise of some discretion. ${ }^{10}$ If he wishes to embrace the first thesis I distinguished, therefore, he must describe a form of social rule that does in fact capture or at least provide for all these principles. This he attempts to do, and he proposes to use my own arguments against me. He admits that the development of a fundamental test for law would be extremely laborious, but he believes that it is in principle possible. He believes, further, that the nerve of any such ultimate test would lie in the concept of "institutional support" that I developed in my original article. He quotes the following passage from that article as authority for his own position:

14. Raz at 852. Carrio, supra note 2, at 25, uses the same term and concept.

15. 115 N.Y. 506, 22 N.E. 188 (1889).

16. Sartorius, supra note 2 , at 155 . 
[I]f we were challenged to back up our claim that some principle is a principle of law, we would mention any prior cases in which that principle was cited, or figured in the argument. We would also mention any statute that seemed to exemplify that principle (even better if the principle were cited in the preamble of the statute, or in the committee reports or other legislative documents that accompanied it). Unless we could find some such institutional support, we would probably fail to make out our case, and the more support we found the more weight we could claim for the principle. ${ }^{17}$

Of course Professor Sartorius would want to develop this doctrine of institutional support in much more detail than that. I myself should elaborate it in the following way, ${ }^{18}$ and his article suggests that he might accept this elaboration. Suppose we were to gather together all the rules that are plainly valid rules of law in, for example, a particular American state, and add to these all the explicit rules about institutional competence that we relied upon in saying that the first set of rules were indeed valid rules of that jurisdiction. We would now have an imposing set of legal materials. We might then ask what set of principles taken together would be necessary to justify the adoption of the explicit rules of law and institutional rules we had listed. Suppose that each judge and lawyer of that state were to develop a "theory of law" which described that set of principles and assigned relative weights to each ( $\mathrm{I}$ ignore the fact that the labor of a lifetime would not be enough for a beginning). Each of them might then argue that his set of principles must count as principles of the legal system in question.

We might formulate the test for law that this story suggests in this way: a principle is a principle of law if it figures in the soundest theory of law that can be provided as a justification for the explicit substantive and institutional rules of the jurisdiction in question. Sartorius says, apparently with this sort of test in mind, that "[a]lthough perhaps it is a good way from Hart's version of positivism it is in accord witn the fundamental positivist tenet as described by Dworkin, viz. that 'the law of a community ... can be identified and distinguished by specific criteria, by tests having to do not with . . . content but with ... pedigree...." "19

But some clarification is now needed. Sartorius could not mean that any particular lawyer's theory of law provides a social rule of recogni-

17. Id. at 156, quoting Dworkin, supra note 1 , at 41 .

18. I did so, at some length, in my inaugural lecture delivered in June 1971, and which I am preparing for publication.

19. Sartorius, supra note 2, at 156, quoting Dworkin, supra note 1 , at 17. 
tion. If I had developed a theory of law for a particular jurisdiction I might well hold that theory as a normative theory of judicial duty, in the spirit of the second thesis I distinguished. If most judges in the jurisdiction each had such a theory, then the third thesis would hold, for that jurisdiction. But each judge's theory would be more or less different from that of the next judge. Some of the principles he advances would be different, and some of those that are the same would differ in weight. These differences insure that no one lawyer's theory can itself be taken as a complex social rule of the sort required by the first thesis.

So Sartorius must say, not that any particular lawyer's theory of law supplies a social rule of recognition, but rather that the test of institutional support itself is such a social rule. He might say, that is, that the social rule of recognition is just the rule that a principle must be applied as law if it is part of the soundest theory of law, and must be applied with the weight it is given by that theory. On this view, the different theories of law different lawyers would offer are simply different theories about how social rules should be applied to particular cases.

But I do not see how one can put the matter that way, and still retain the idea that the test of institutional support provides "specific criteria" of "pedigree" rather than "content." The concept of a theory of law, in the way I described it, does not suppose that principles and policies explain the settled rules in the way in which a legal historian might explain them, by identifying the motives of those who adopted these rules, or by calling attention to the pressure groups which influenced their enactment. If a theory of law is to provide a basis for judicial duty, then the principles it sets out must try to justify the settled rules by identifying the political or moral concerns and traditions of the community which, in the opinion of the lawyer whose theory it is, do in fact support the rules. This process of justification must carry the lawyer very deep into political and moral theory, and well past the point where it would be accurate to say that any "test" of "pedigree" exists for deciding which of two different justifications of our political institutions is superior.

The simple example I gave earlier illustrates the point. If I disagree with another lawyer about the relative force to be given to older precedents, I will urge a theory of law that takes a view of the point of precedent that supports my case. I might say that the doctrine of precedent serves equality of treatment before the law, and that simplicity of treatment becomes less important and even perverse as the time 
elapsed between the two occasions increases. He might reply that the point of precedent is not so much equality as predictability of decision, which is best served by ignoring distinctions of age between precedents. Each of us will point to features of adjudication that support one view against the other. If one of us could find none, then, as I said in the quoted passage, his case would be weak. But the choice between our views will not depend only on the number of features each can find. It will depend as well on the moral case I can make for the duty of equal treatment that my argument presupposes, because the thesis that this duty justifies precedent assumes that the duty exists.

I do not mean to say that no basis can be found for choosing one theory of law over another. On the contrary, since I reject the doctrine of discretion described in the next section, $I$ assume that persuasive arguments can be made to distinguish one theory as superior to another. But these arguments must include arguments on issues of normative political theory, like the nature of society's duty of equality, that go beyond the positivist's conception of the limits of the considerations relevant to deciding what the law is. The test of institutional support provides no mechanical or historical or morally neutral basis for establishing one theory of law as the soundest. Indeed, it does not allow even a single lawyer to distinguish a set of legal principles from his broader moral or political principles. His theory of law will usually include almost the full set of political and moral principles to which he subscribes; indeed it is hard to think of a single principle of social or political morality that has currency in his community and that he personally accepts, except those excluded by constitutional considerations, that would not find some place and have some weight in the elaborate scheme of justification required to justify the body of laws. So the positivist will accept the test of institutional settlement as filling the role of his ultimate test for law only at the cost of abandoning the rest of his script.

If that is so, then the consequences for legal theory are considerable. Jurisprudence poses the question: what is law? Most legal philosophers have tried to answer this question by distinguishing the standards that properly figure in arguments on behalf of legal rights and duties. But if no such exclusive list of standards can be made, then some other way of distinguishing legal rights and duties from other sorts of rights and duties must be found. 


\section{Do Judges Have to Have Discretion?}

I must now discuss, once again, the second of the two strategies for positivism that I distinguished at the beginning of the last section. This is the argument that when judges disagree about matters of principle they disagree not about what the law requires but about how their discretion should be exercised. They disagree, that is, not about where their duty to decide lies, but about how they ought to decide, all things considered, given that they have no duty to decide cither way.

I tried to explain, in my original article, that this argument in fact depends upon a kind of ambiguity in the concept of discretion. We use that concept, in discussions about duty, in three different ways. First, we say that a man has discretion if his duty is defined by standards that reasonable men can interpret in different ways, as a sergeant has discretion if he is told to take the five most experienced men on patrol. Second, we say that a man has discretion if his decision is final, in the sense that no higher authority may review and set aside that decision, as when the decision whether a player is offside is left to the discretion of the linesman. Third, we say that a man has discretion when some set of standards which impose duties upon him do not in fact purport to impose any duty as to a particular decision, as when a clause in a lease gives the tenant the option in his discretion to renew.

It is plain that if no social rule unambiguously requires a particular legal decision, and the profession is split on what decision is in fact required, then judges will have discretion in the first of these senses, because they will have to exercise initiative and judgment beyond the application of a settled rule. It is also plain, if these judges form the highest court of appeal, that they will have discretion in the second sense. But, unless we accept the strongest form of the social rule theory, that duties and responsibilities can be generated only by social rules, it does not follow that these judges have discretion in the third sense. A judge may have discretion in both the first and second senses, and nevertheless properly regard his decision as raising an issue of what his duty as a judge is, an issue which he must decide by reflecting on what is required of him by the varying considerations that he believes are pertinent. If so, then this judge does not have discretion in the third sense, which is the sense a positivist needs to establish if he is to show that judicial duty is defined exclusively by an ultimate social rule or set of social rules.

Raz was not persuaded by my argument. ${ }^{20} \mathrm{He}$ repeats the distinction

20. Raz at 843 ff. See MacCallum, supra note 2. 
that I drew among these three senses of discretion, but having repeated that distinction he ignores it. He apparently thinks that I meant to argue as follows. (i) Judges have no discretion with respect to a decision when they all agree that a particular set of principles is decisive. (ii) That is sometimes the case even when no rule of law settles the case. (iii) Therefore it is never the case that judges have discretion when no rule settles the case.

That is a fallacious argument; fortunately it is not mine. Judges are sometimes united on a set of principles. But even when they are divided on principles they sometimes treat the issue as one of judicial responsibility, that is, as one that raises the question of what, as judges, they have a duty to do. In such a case they have discretion in the first sense I distinguished, but that is irrelevant. They nevertheless do not believe they have discretion in the third sense, which is the sense that counts.

Why should Raz ignore the distinctions I drew? He supposes that there are features of any legal system that have this consequence: If judges have discretion in the first sense, because no social rule directly or indirectly dictates the result they must reach, then they must also have discretion in the third sense, so that their decision cannot be a matter of judicial duty. Judges may be mistaken in this; they may inappropriately use the language of duty. But we must not, as Raz says, perpetuate mistakes just because they are popular. Still, it is necessary to show that they are mistakes, and Raz does not. What arguments might he make?

Raz's inclination, to convert discretion in the first into discretion in the third sense, is extraordinarily common among legal philosophers. ${ }^{21}$ We must try to diagnose its source. When a judge faces a difficult decision he must suppose, before beginning his research, that there are in principle these three possibilities. The set of standards that he must take into account, taken together, require him to decide for the plaintiff, or require him to decide for the defendant, or require neither decision but permit either one. He must also recognize that he might be to some degree uncertain which of these three possibilities in fact holds; in that case he must decide on the basis of the case that seems to him the strongest. But that uncertainty might apply just as mutch to the third possibility as to the other two; the law might grant him a discretion, in the third sense, to reach either decision, but whether it does is a matter of what the legal materials, taken together, come to,

21. It is displayed in all the articles listed in note 6 supra. 
and one may be as uncertain whether the materials justify that conclusion as either of the other two.

$\mathrm{Raz}$ apparently thinks that if it is uncertain whether the first or the second possibility is realized, then it follows that the third is. He thinks, that is, that if a judge is uncertain whether to decide for the plaintiff or defendant it follows that he should be certain that he has discretion to decide for either. I can think of only two arguments to support that extraordinary conclusion.

The first depends on the assumption of moral philosophy I described earlier, that duties cannot be controversial in principle. Raz makes that assumption, because he argues from the fact that judges may disagree about principles, and particularly about their weight, to the conclusion that judges must have discretion in the sense I deny. That is a non sequitur unless something like that assumption holds, but we have no reason to suppose that it does, as I said, once we reject the strong version of the social rule theory.

The second argument relies on a different assumption, namely that every legal system contains a rule of decision which provides affirmatively that judges have discretion in hard cases. Some legal systems may employ such a rule. But the English and American systems do not. They contain no such explicit rule, nor as Raz agrees, does judicial behavior show that any such rule is recognized implicitly.

On the contrary, for us the proposition that judges have discretion in the third sense on some issue or other is a proposition that must be established affirmatively, on the balance of argument, and not simply by default. Sometimes judges do reach that conclusion; for example, when passing sentences under criminal statutes that provide a maximum and minimum penalty, or when framing equitable relief under a general equity jurisdiction. In such cases judges believe that no one has a right to any particular decision; they identify their task as selecting the decision that is best on the whole, all things considered, and here they talk not about what they must do but about what they should do. In most hard cases, however, judges take the different posture I described. They frame their disagreement as a disagreement about what standards they are entitled or obliged to take into account, or what relative weights they are obliged to attribute to these, on the basis of arguments like the arguments I described in the last section illustrating the theory of institutional support. In such cases, some judges argue for the first possibility I mentioned, others for the second and others are undecided; but all exclude the third. There is plainly not even the beginnings of a social rule that converts the discretion that requires judgment into the discretion that excludes duty. 


\section{Are Rules Really Different from Principles?}

In my article I distinguished rules from principles by distinguishing the different force that the two types of standards have in argument. My purpose was twofold: first, to call attention to a distinction which I thought was of importance in understanding how lawyers reason, and second, to call attention to the fact that some of the standards to which judges and lawyers appeal pose special problems for positivism, because these standards cannot be captured under a fundamental test for law like Hart's rule of recognition. These two purposes were distinct; even if the particular logical distinction that I claim between rules and principles can be shown to be spurious, it might still be that standards like those I mentioned, however identified, and whether or not classified as rules, cannot be captured by any such test. If I do not succeed in establishing my distinction between rules and principles, therefore, it by no means follows that the general argument I make against legal positivism is undermined.

Nevertheless, I do continue to think that the distinction that I drew between rules and principles is both genuine and important, and I should want to defend it. I do not mean, of course, that it is wrong to draw other sorts of distinctions among types of legal standards, or even that it is wrong or confusing to use the terms "rule" and "principle" to make these distinctions rather than the one I drew.

Raz's chief objection to my distinction might be put this way. ${ }^{22}$ I argued that principles, like those I mentioned, conflict and interact with one another, so that each principle that is relevant to a particular legal problem provides a reason arguing in favor of, but does not stipulate, a particular solution. The man who must decide the problem is therefore required to assess all of the competing and conflicting principles that bear upon it, and to make a resolution of these principles rather than identifying one among others as "valid." Raz wishes to argue that it is not simply principles that properly conflict with one another in this way, but rules as well, and he believes that this fact undermines the distinction that I have drawn. He offers exam. ples from both moral and legal argument. I shall consider each set of examples in turn.

Raz has it in mind that a man might accept, as moral rules for the guidance of his conduct, both the rule that one must never tell a lie and the rule that one must always keep his promises. He points out that on particular occasions these two rules might conflict, and require

22. It is developed in $\operatorname{Raz}$ at 829 ff. 
the man who accepts them both to choose between them on the basis of which under the circumstances has the greater weight, or importance, or on some other basis. He concludes that moral rules follow the logic that I described for principles, that is, that they point in one direction though they are not necessarily decisive of any moral issue.

But, in the first place, though it is possible that a man might accept moral rules for the guidance of his conduct in the way this argument assumes, it is far from the case that most men who take morality seriously do anything of the sort. For most people moral argument or decision is a matter of giving reasons for or against the morality of a certain course of conduct, rather than appealing to rules set down in advance whether by social or individual decision. It is true that a moral man may find himself in difficulty when he must choose between telling a lie or breaking a promise, but it does not follow that he has accepted rules which come into conflict over the issue. He might simply have recognized that telling lies and breaking promises are both in principle wrong.

Of course we might describe his predicament by saying that he was forced to choose between two moral.standards, even if he would not put the matter that way himself. But in that case, if we use the distinction I made, we should say that he was forced to resolve competing principles, not rules, because that would be the more accurate way of describing his situation. He recognizes that no moral consideration is by itself of overwhelming and overriding effect, and that any reason that counts against an act may in some circumstances have to yield to a competing consideration. Any philosopher or sociologist who wants to report his moral practices in terms of a code of standards must therefore say that for him morality is a matter of principle and not of rule.

But it is possible that some man might accept a moral rule for the guidance of his conduct in the way that Raz supposes. He might say, for example, that he has undertaken a personal commitment never to tell a lie. If he can accept one flat moral rule in this way, then he can accept others, and these may conflict in the way the example supposes. It would then be wrong to say, using my distinction, that this man has simply accepted a set of principles which might in principle conflict, because that wrongly describes his attitudes towards the several commitments he believes he has made. He believes he is committed to his different standards as rules, that is, as propositions which demand a particular course of conduct in the circumstances they name.

But I did not deny, in my original article, that conflicts in rules 
might exist. I said that in our legal system such conflicts would be occasions of emergency, occasions requiring a decision that would alter the set of standards in some dramatic way. Indeed this description fits the present non-legal example as well. Our moral hero, if he understands at all the concepts he has been using, cannot continue to say, after he has resolved his conflict that he has been following both of his standards as flat rules. If he still wishes to present his morality as a consistent code, he may amend one or both of them to provide for the conflict, or he may revise his attitude towards one or both so as to convert them from rules into principles. He may do neither, but rather, when a conflict appears, announce himself to be in a state of moral dilemma, and do nothing, or flip a coin or decide in some other irrational way that the legal system does not permit. In any case, the distinction between rules and principles that I drew, so far from being called into question by the behavior of this unusual man, is in fact needed to explain it.

Raz takes his other examples from law. He calls our attention, for example, to rules of criminal law like the rule that prohibits an assault; this rule, he says, is in conflict with another rule which permits assault in self defense. Here, he concludes, we have two legal rules, both of them plainly valid which are in conflict with one another. $\mathrm{He}$ believes that in particular cases, when these two rules do conflict, as they will when someone commits an assault in self defense, it is necessary for the judge to weigh the rules and decide to apply the more important, which will always be the rule that permits an assault in self defense. He offers this as an example of two rules which conflict acceptably, and with no sense of emergency, in the way that I said rules do not.

But this example surely rests on a bizarre notion of what a conflict is. If a criminal code contains a general rule to the effect that no one shall be criminally liable for an act committed in self defense, then that rule does not conflict with particular rules defining particular crimes, even if these particular rules make no mention of self defense. The general rule about self defense must be read to mean that notwithstanding the particular rules of criminal law, no act shall be a crime if committed in self defense. Indeed, rules providing general defenses are often drafted in just this way, but even when they are not, they are understood in that way. But a rule that provides an exception to another rule is not in conflict with that other rule, at least not in the way in which two principles conflict. It would be silly to say that when a man accused of assault has proved a case of self: 
defense, the judge is then faced with two rules pulling in opposite directions, which he has somehow to weigh against one another in reaching his decision. The two rules taken together determine the result in a manner which does not require the judge to choose between them, or to determine their relative importance.

Why should Raz suppose that two rules are in conflict even when one has plainly the force of an exception to the other? The answer lies, I think, in what he says about the individuation of laws. ${ }^{23} \mathrm{He}$ supposes that I would want to answer his point, that the rule prohibiting assault conflicts with the rule permitting assault in self defense, by arguing that these two rules are really part of the same rule. He says that I could do that only at the price of accepting an unacceptable theory about the individuation of laws, and, anticipating such a mistake on my part, he says, that I pay insufficient attention to the general problem of the individuation of laws. In this he is too generous for it would be more accurate to say that I pay no attention to that problem at all. I did not in fact rely upon the argument that a rule and its exception really count as one rule, but neither would I be disposed to argue that they must be in reality two rules.

$\mathrm{Raz}$ is of two minds about his theory of individuation of laws. Sometimes he treats a theory of individuation as a strategy of exposition, that is to say, a theory about the most illuminating way in which the legal system of a nation may be described. Plainly, the author of a textbook on criminal law, for example, needs a strategy of exposition. He needs to distinguish the doctrine of mens rea from the doctrine of necessity and to distinguish both of these general doctrines from the more particular rules which they cut across as qualifications and exemptions. But of course, though some strategies of exposition might be perverse or misguided, because they describe the law in an unruanageable or unassimilatable form, a great many different strategies might be more or less equally competent.

At other times, however, Raz seems to think that the problem of individuation of laws has to do, not with any strategy of explaining what the law is to students or lawyers, but with the more philosophical question of what law is. He says that it is a problem about the formal structure of the law, which is of importance to the legal philosopher, and not to the author of a text. He poses the central problem in this way: "What is to count as one complete law?", and he adopts Bentham's elaboration of this question: "What is a law? What the part of a law? The subject of these questions, it is to be observed, is the

23. Raz at $825 \mathrm{ff}$. 
logical, the ideal, the intellectual whole, not the physical one . . .".94

This sort of question carries us very far away from techniques of legal exposition: it carries us to the point at which, as Dr. Raz insists, theories of law may rise or fall depending upon the right answer to the question, "What is to count as one complete law?"' That seems to me much too far. Suppose that you have read a long book about geology, and I ask you to tell me what information it contains. You will do so in a series of propositions of fact. But now suppose $I$ ask you first how many propositions of fact the book contains, and what theory you used in counting them. You would think me mad, not simply because the question is preposterously difficult, as if I had asked you how many separate grains of sand there were in a particular beach, or because it requires a difficult conceptual discrimination, as if I had asked you how many human beings there were in a group that included a woman in early pregnancy. You would think me mad because I had asked entirely the wrong sort of question about the material at hand. The book contains a great deal of information; propositions are ways of presenting that information, but the number of propositions used will depend on considerations independent of the content of the information, such as, for example, whether one uses the general term "rocks" or the names of particular sorts of rocks.

In the same way, lawyers use rules and principles to report legal information, and it is wrong to suppose that any particular statement of these is canonical. This is true even of what we call statutory rules, because it is a commonplace that lawyers will often misrepresent the rules that a statute enacted if they simply repeat the language that the statute used. Two lawyers might summarize the effect of a particular statute using different words, and one might use more rules than another; they might still both be saying the same thing.

My point was not that "the law" contains a fixed number of standards, some of which are rules and others principles. Indeed, I want to oppose the idea that "the law" is a fixed set of standards of any sort. My point was rather that an accurate summary of the considerations lawyers must take into account, in deciding a particular issue of legal rights and duties, would include propositions having the form and force of principles, and that judges and lawyers themselves, when justifying their conclusions, often use propositions which must be understood in that way. Nothing in this, I believe, commits me to a legal ontology that assumes any particular theory of individuation.

24. $\operatorname{Raz}$ at 825 .

25. Raz at $825,827-28$. 
I did say that a "full" statement of a legal rule would include its exceptions, and that a statement of a rule that neglected the exceptions would be "incomplete." I would not have put the point that way had I been aware of Raz's objection. I would have made plain that an exception can be stated in the form of a distinct rule, like the rule about self-defense, as well as in the form of a revised statement of the original rule. But if I had I would also have made plain that the difference is largely a matter of exposition. The distinction between rules and principles remains untouched. I might summarize a body of law by stating a rule, like the rule that an assault is a crime, and a list of established exceptions. If my summary is complete then anyone who commits an assault is guilty of a crime unless an exception I stated applies; if he is not guilty, then either I was wrong or the law has changed. It is otherwise in the case of a principle. If I say that in principle someone may not profit from his own wrong but someone does, because someone may properly profit from his own wrong, as these terms must be understood, not only when a recognized exception applies, but when special features of his case invoke some other, newly-recognized, principle or policy that makes a difference; then my statement need not be corrected, or even brought up-to-date.

It is his second, ontological, mood about the individuation of laws that leads Raz to his curious view about conflicts. If one takes seriously the idea that rules of law are in certain forms "whole" and "complete," then one may be tempted to think that whole and com. plete laws are also independent of one another, so that the rule defining assault must then be taken as a flat direction that men who do certain acts be punished. But if we take the statement of a rule of law as an attempt merely to describe the legal effect of certain institutional decisions, we are not tempted to suppose any such conflict. We shall then say merely that the rule about assault, like many of the rules about crimes, is subject to an exception in cases of self-defense; we shall not then worry about whether we have described one rule or two.

Raz has another argument against my distinction, which I do not fully understand. He argues that the distinction is undercut by the fact that rules may conflict with principles; the rules of adverse possession, for example, may be thought to conflict with the principle that no man may profit from his own wrong. I do not think it illuminating to describe the relationship between these rules and that principle as one of conflict. The fact that such rules exist, is, as I said, evidence that the principle about not profiting from one's wrong is indeed a principle and not a rule. If the rules of adverse possession 
are some day amended, either by explicit legislative enactment or by judicial reinterpretation, then one reason might be that the principle is then recognized as being more important than it was when the rules were adopted. Nevertheless, the rules governing adverse possession may even now be said to reflect the principle, rather than conflict with it, because these rules have a different shape than they would have had if the principle had not been given any weight in the decision at all. The long length of time generally required for acquiring title by adverse possession might have been much shorter, for example, had this not been thought to conflict with the principle. Indeed, one of my rensons for drawing the distinction between rules and principles was just to show how rules often represent a kind of compromise amongst competing principles in this way, and that point may be lost or submerged if we speak too freely about rules conflicting with principles.

In any event, I cannot see how this phenomenon casts doubt upon the distinction I want to draw between rules and principles. Raz thinks that it shows that rules as well as principles have weight, because he thinks that when rules and principles conflict a decision must be made as to which of them to prefer, and this decision must be made by assigning a weight to the rule which is then set against the weight of the principle. But this description surely misrepresents the interaction between rules and principles. Suppose a court decides to overrule an established common law rule that there can be no legal liability for negligent misstatements, and appeals to a number of principles to justify this decision, including the principle that it is unjust that one man suffer because of another man's wrong. The court must be understood as deciding that the set of principles calling for the overruling of the established rule, including the principle of justice just mentioned, are as a group of greater weight under the circumstances than the set of principles, including the principle of stare decisis, that call for maintaining the rule as before. The court weighs two sets of principles in deciding whether to maintain the rule; it is therefore misleading to say that the court weighs the rule itself against one or the other set of these principles. Indeed, when Raz describes the weighing of either a legal or a moral rule, he in fact talks about weighing the principles and policies that the rule serves, because that must be what he means when he speaks of the "goal" of the rule.

I cannot reply to all the further points of detail Raz makes in his article, but I should like to comment briefly on some of them.

(1) Raz endorses a different distinction between rules and prin- 
ciples from the one I drew.. ${ }^{20}$ He prefers a distinction according to which rules prescribe relatively specific acts and principles relatively unspecific acts. ${ }^{2 \tau}$ "An act is highly unspecific," Raz says, "if it can be performed on different occasions by the performance of a great many heterogeneous generic acts on each occasion." $=8$ But this is unsatisfactory, for he fails to specify, except by example, his criteria for the heterogeneity of "generic acts," and his examples confuse rather than illuminate. He says that the proposition that one must keep one's promises is a rule, and he uses that proposition to illustrate his thesis that rules may conflict with one another. But the most varied sorts of acts can each, in different circumstances, be acts that keep promises, because anything that a man may do he may also promise to do. $\mathrm{Raz}$ says, on the other hand, that "a law instructing the courts and all public officials to protect freedom of speech" would be a principle. But the acts that officials would be required to perform in the light of this principle would all be acts of giving orders or casting votes, and those would seem more homogeneous, and certainly not less homogeneous, than the acts they would be required to do to keep all their promises as individuals. Of course, all acts of promise-keeping are alike in being acts of promise-keeping. But all acts of protecting free speech or even promoting equality are alike in the same way. Whether a group of acts is homogeneous depends upon the description under which they are considered, and until Raz offers a theory of canonical description his distinction is one we cannot use.

(2) $\mathrm{Raz}$ is right that some statements that begin, "It is a principle of our law that ...," should be understood as merely summaries of other standards. ${ }^{29}$ But he is wrong in supposing that a court's reference to the principle of freedom of contract, for example in the Henningsen case I discussed, should be understood in that way. On the contrary, these references recognize the force of a principle in determining particular legal rights and duties, and attempt to assess and sometimes to limit that force.

(3) Raz misunderstands the point I made about the use of words like "reasonable" in rules. ${ }^{30} \mathrm{I}$ did not mean that it was the function of such words to "immunize the law" against general considerntions embodied in certain principles. ${ }^{31}$ I meant rather that it was their

\footnotetext{
26. Raz at $838 \mathrm{ff}$.

27. Raz at 838 .

28. Id.

29. Raz at 828-29.

30. Raz at 837-38.

31. See Raz at 837 .
} 
function to open rules to the effect of certain principles, but only certain principles. The rule that unreasonable restraints of trade are invalid remains a rule if every restraint that is unreasonable is invalid, even if other reasons for enforcing it, not mitigating its unreasonableness, might be found. The principle that Raz cites as on all fours with such a rule, that the courts generally refuse to enforce unjust bargains, is by its own terms different in that sense. This principle contemplates that unjust bargains may indeed be enforced when unusual circumstances require; for example, perhaps, when no other way to protect innocent third parties can be found. It would be otherwise if the legislature had enacted a rule that unjust bargains are void and unenforceable.

(4) Raz is right in supposing that very few large communities share a consistent code of moral beliefs, but he misunderstands those judges who appeal to community morality, whom he accuses of propagating a harmful fiction. ${ }^{32} \mathrm{He}$ fails to distinguish between concepts of the moral standards of a community. That phrase may refer to a consensus of belief about a particular issue, as might be elicited by a Gallup poll. Or it may refer to moral principles that underlie the community's institutions and laws, in the sense that these principles would figure in a sound theory of law of the sort discussed earlier in this essay. Whether a principle is a principle of the community in this sense would be a matter for argument, not report, though typically the weight of the principle, not its standing, would be at issue. The judges Raz criticizes use the concept in this second sense, though they sometimes do so in language that is consistent with the first. Raz mistakes their failure to notice a sophisticated distinction for hypocrisy. Is it far-fetched to suppose that his own failure to notice that distinction reflects his reliance on the social rule theory? If the strong version of that theory were right then one could not argue that a community was committed to any morality of duty, by its traditions and institutions, except the morality recognized in its uniform social practices, which generally embrace little of much significance. This is, I think, the most important consequence of the social rule theory for jurisprudence, and the most compelling reason for insisting that that theory is wrong.

32. Raz at 850-51. 